\title{
大都市における寺院墓地空間の変容に関する研究 SPATIAL TRANSFORMATIONS IN THE GRAVEYARDS OF URBAN TEMPLES
}

\author{
尾 崎友 紀*, 平山洋介** \\ Yuki OSAKI and Yosuke HIRAYAMA
}

\begin{abstract}
This paper looks at transformations in urban temple graveyards. There has been a tacit image that temples are concerned with maintaining the conventional system of graveyard management. However, it is not necessarily appropriate to emphasize the traditional nature of temple graveyards. The paper, drawing on a field survey on temples in the Tokyo metropolitan area, demonstrates that urban temples have undertaken to address contemporary graveyard issues caused by a decline in traditional-style families, an increase in deaths of single people and diversified needs for graveyard design.
\end{abstract}

Keywords: graveyard, grave, temple, family, tradition, Tokyo 墓地、墳墓、寺院、家、伝統、東京

\section{1. 研究の目的と方法}

本稿は、都市に立地する寺院墓地の空間特性とその変容実態を明 らかにしようとするものである。人口の高齢化が進み、地方から都 市に移動した人びとの多くが都市部で墓地を求め始めたことから、 都市部での墓地需要はいっそう拡大寸ると考えられている。また、 少子化の進行、無配偶者の増加、家族観の変化などによって、伝統 的な家墓 ${ }^{1)}$ の存立基盤が摇らぎ、より多様な墓地のあり方が模索さ れている2)。こうした社会変化は、都市と墓地の関係に関する再考 の必要をもたらしている。

これまでの墓地政策は、市街地に立地する狭小な墓地を廃止し、 その郊外移転の促進を基本方針としていた。関東大震災後の東京都 心部からの墓地移転、終戦後の名古屋市における大規模な墓地移転 事業など、市街地における墓地立地の制限、郊外での墓地開発とい う方向性が墓地政策を歴史的に特徴づけてきた ${ }^{3)}$ 。郊外に新たに設 置される墓地は家墓を基本とし、そこでは墓所区画の規格化、公園 のような景観形成、衛生と美観が重視された ${ }^{4)}$ 。地域の習俗、宗教 の伝統のなかで長く営まれてきた墓地は整理の対象とされ、市街地 での墓地の新規開設は法令によって規制されてきた。しかし、公共 セクターによる郊外での大型の墓地開発は 1970 年代に終焉し、市街 地立地の墓地に対寸る需要が増えている ${ }^{5)}$ 。この点から都市内の既
存の墓地を再評価し、その整備を進める必要が指摘されている ${ }^{6)}$ 。

都市に長い期間にわたって存続し、様々な社会変化の影響を受け てきた墓地のタイプのひとつが寺院墓地である。本稿では仏教系宗 教法人を経営主体と寸る墓地を寺院墓地と定義している。ここには、 墓地使用者を檀家のみとする檀家用墓地に限らず、使用に際して宗 旨を問わず他宗教または仏教他宗派の僧侶による供養の執行も可能 な、いわゆる民間霊園も含まれる。都市の寺院墓地は人びとの生活 圈に長期間存在し、都市空間を構成する一要素としての役割を果た してきた。墓地は死者を葬るための空間として存立するだけではな く、宗教・信仰の場、緑地・空地を形成し、寺院と地域の関係をつ くる機能をも有している。墓地需要の増大が予想される状況下にお いて、既存の寺院墓地がどのような役割を果たしているのか、その 役割はどのように変容しているのか、を検討することが本稿の関心 事である。

本稿は東京都の寺院墓地を対象として実施した調査に基づく。現 在の東京では、ほかの都市に比べ地方出身者が多いために核家族化 が一層進み、独身者も多いなど、家族の変化が進んでいることから、 それにともなう墓地の変容が顕著に現れている ${ }^{7)}$ 。また、東京では 市街地での墓地の使用希望者が増加寸る傾向がみられている ${ }^{8)}$ 。都 内の墓地供給に関しては、郊外立地の大規模な都立霊園が大きな役
* 高知県庁

** 神戸大学大学院人間発達環境学研究科 教授. 学博
Kochi Prefecture

Prof., Graduate School of Human Development and Environment, Kobe University, Ph. D. 
割を担っているが、今後その新規開設の見込みがない点を考慮する と、市街地立地の寺院墓地は貴重な墓地供給主体であり、その重要 性が増しているといえる ${ }^{9)}$ 。

日本の墓地に関寸る既存研究としては、墓地・葬送の習俗に関す 万研究 ${ }^{10)}$ や、近代以降を中心とした墓地行政についての研究 ${ }^{11)}$ な どが多く、建築・都市計画の分野では、墓地の空間利用や設備に関 する研究などが中心であった ${ }^{12)}$ 。これに対し、近年では家の継続性 を前提と寸る墳墓承継の困難化という問題を対象とし、家墓が必ず しも成り立つとはいえなくなった現代における新たな墓所形態を扱 う研究 ${ }^{13)}$ などが増えている。しかし、これらの新たな研究は、墓 地使用者の変容に焦点を合わせている。本研究は、墓地を供給・経 営する側としての寺院に着目した点に特徴をもつ。本稿は、墓地の 物的変容に加え、墓地経営者と使用者の関係の変化、経営者の意識 と対応を分析するところから、都市における寺院墓地空間の変容を 考察し、寺院墓地に関する新たな知見を得ようとするものである。

以下では、まず都内の寺院を対象として実施したアンケート調査 の結果の分析を行う ( 2 章)。ここでは寺院墓地の実態と変容傾向を 捉えることを主眼としている。この結果を踏まえ、墓地または納骨 堂を経営する寺院を対象として実施したインタビュー調査の結果を もとに、墓地使用の変化、それへの寺院の意識と対応をより詳細に 分析する (3 章)。それぞれの調査手法は各章において述べる。

\section{2. 寺院墓地の実態と変容}

本章では、東京の寺院墓地の物理的な空間実態とその恋容を把握 する。『東京都宗教法人名簿 平成 16 年度版』 ${ }^{14)}$ に掲載されている、 東京都（島嶼部を除く）に立地する全仏教系宗教法人に対し 2005 年 11 月にアンケート調査を行った。2,794 寺院にアンケート票を郵送し、

表 1 地域別 面積別墓地数

\begin{tabular}{|c|c|c|c|c|c|c|c|c|}
\hline & \multicolumn{2}{|c|}{ 区部 } & \multicolumn{2}{|c|}{ 多摩地域 } & \multicolumn{2}{|c|}{ 不明 } & \multicolumn{2}{|c|}{ 合計 } \\
\hline$\sim 499 \mathrm{~m}^{2}$ & 38 & $(20.0 \%)$ & 2 & $(3.8 \%)$ & 0 & $(0.0 \%)$ & 40 & $(16.4 \%)$ \\
\hline $500 \mathrm{~m}^{2} \sim$ & 48 & (25.3\%) & 11 & $(21.2 \%)$ & 1 & $(50.0 \%)$ & 60 & (24.6\%) \\
\hline $1,000 \mathrm{~m}^{2} \sim$ & 56 & (29.5\%) & 12 & (23.1\%) & 1 & (50.0\%) & 69 & (28.3\%) \\
\hline $2,000 \mathrm{~m}^{2} \sim$ & 30 & (15.8\%) & 16 & $(30.8 \%)$ & 0 & $(0.0 \%)$ & 46 & $(18.9 \%)$ \\
\hline $4,000 \mathrm{~m}^{2} \sim$ & 15 & ( $7.9 \%)$ & 7 & (13.5\%) & 0 & $(0.0 \%)$ & 22 & $(9.0 \%)$ \\
\hline $10,000 \mathrm{~m}^{2} \sim$ & 3 & ( $1.6 \%)$ & 4 & $(7.7 \%)$ & 0 & $(0.0 \%)$ & 7 & ( $2.9 \%)$ \\
\hline 合計 & 190 & $(100 \%)$ & 52 & $(100 \%)$ & 2 & $(100 \%)$ & 244 & $(100 \%)$ \\
\hline
\end{tabular}

注) 面積が不明の回答を除く。

表 2 地域別 墓所区画面積別墓地数

\begin{tabular}{|c|c|c|c|c|c|c|c|c|}
\hline & \multicolumn{2}{|c|}{ 区部 } & \multicolumn{2}{|c|}{ 多摩地域 } & \multicolumn{2}{|c|}{ 不明 } & \multicolumn{2}{|c|}{ 合計 } \\
\hline$\sim 0.49 \mathrm{~m}^{2}$ & 12 & $(7.1 \%)$ & 0 & $(0.0 \%)$ & 0 & $(0.0 \%)$ & 12 & $(5.4 \%)$ \\
\hline $0.50 \mathrm{~m}^{2} \sim$ & 40 & (23.8\%) & 3 & ( $5.9 \%)$ & 1 & $(50.0 \%)$ & 44 & $(19.9 \%)$ \\
\hline $1.00 \mathrm{~m}^{2} \sim$ & 63 & (37.5\%) & 8 & (15.7\%) & 1 & $(50.0 \%)$ & 72 & $(32.6 \%)$ \\
\hline $2.00 \mathrm{~m}^{2} \sim$ & 19 & (11.3\%) & 5 & $(9.8 \%)$ & 0 & $(0.0 \%)$ & 24 & $(10.9 \%)$ \\
\hline $3.00 \mathrm{~m}^{2} \sim$ & 20 & (11.9\%) & 18 & $(35.3 \%)$ & 0 & $(0.0 \%)$ & 38 & $(17.2 \%)$ \\
\hline $4.00 \mathrm{~m}^{2} \sim$ & 0 & $(0.0 \%)$ & 6 & (11.8\%) & 0 & $(0.0 \%)$ & 6 & $(2.7 \%)$ \\
\hline $5.00 \mathrm{~m}^{2} \sim$ & 1 & $(0.6 \%)$ & 4 & $(7.8 \%)$ & 0 & $(0.0 \%)$ & 5 & ( $2.3 \%)$ \\
\hline $\begin{array}{l}\text { 多様な規模の } \\
\text { 区画が混在 }\end{array}$ & 13 & ( 7.7\%) & 7 & $(13.7 \%)$ & 0 & $(0.0 \%)$ & 20 & ( $9.0 \%)$ \\
\hline 合計 & 168 & $(100 \%)$ & 51 & $(100 \%)$ & 2 & $(100 \%)$ & 221 & $(100 \%)$ \\
\hline
\end{tabular}

注）・墓地で最も多い墓所区画の面積について設問した。 ·墓所区画面積が不明の回答を除く。

表 3 地域別 区画使用率別墓地数

\begin{tabular}{|c|c|c|c|c|c|c|c|c|}
\hline \multirow[b]{2}{*}{$\sim 49 \%$} & \multicolumn{2}{|c|}{ 区部 } & \multicolumn{2}{|c|}{ 多摩地域 } & \multicolumn{2}{|c|}{ 不明 } & \multicolumn{2}{|c|}{ 合計 } \\
\hline & 5 & $(3.0 \%)$ & 6 & $(11.8 \%)$ & $\overline{0}$ & $(0.0 \%)$ & 11 & $(5.1 \%)$ \\
\hline $50 \% \sim$ & 28 & (17.1\%) & 11 & (21.6\%) & 1 & (50.0\%) & 40 & $(18.4 \%)$ \\
\hline $80 \% \sim$ & 37 & $(22.6 \%)$ & 11 & $(21.6 \%)$ & 0 & $(0.0 \%)$ & 48 & (22.1\%) \\
\hline $90 \% \sim$ & 57 & $(34.8 \%)$ & 15 & $(29.4 \%)$ & 0 & $(0.0 \%)$ & 72 & $(33.2 \%)$ \\
\hline $100 \%$ & 37 & $(22.6 \%)$ & 8 & $(15.7 \%)$ & 1 & (50.0\%) & 46 & $(21.2 \%)$ \\
\hline 合計 & 164 & $(100 \%)$ & 51 & $(100 \%)$ & 2 & $(100 \%)$ & 217 & $(100 \%)$ \\
\hline
\end{tabular}

注）保有区画数または使用区画数が不明の回答を除く。
303 票を回収した。都内での墓地経営を行っていない寺院からの回収 票を除き、有効票数は 265 票であった。

\section{$2-1$. 墓地・墓所区画の規模と墳墓の形態}

まず、墓地の規模についての回答をみていく。墓地面積では 2,000 $\mathrm{m}^{2}$ 未満が 69.3\%を占め、小規模な墓地が多い（表 1 ）。地域別に観 察すると、区部では面積のより小さい墓地が多く $1,000 \mathrm{~m}^{2}$ 未満が $45.3 \%$ 、500 $\mathrm{m}^{2}$ 未満が $20.0 \%$ であた。一方、市部と郡部を合わせ た多摩地域では比較的大規模な墓地が多く $2,000 \mathrm{~m}^{2}$ 以上の墓地が $51.9 \%$ を占め、7.7\%は $10,000 \mathrm{~m}^{2}$ 以上であった。墳墓の建立のために 使用者に貸し付けられる墓所一区画あたりの面積も小さいものが多 い。墓地で最も多い墓所区画の面積を 1.00 1.99 $\mathrm{m}^{2}$ と答えた寺院が $32.6 \% 、 1 \mathrm{~m}^{2}$ 未満が $25.3 \%$ あっ（表 2 ）。比較的大きい $3 \mathrm{~m}^{2}$ 台は $17.2 \%$ と少ない。地域別には、区部において狭小な墓所が多いのに 対し、多摩地域の墓所面積は大きい。区部では $1 \mathrm{~m}^{2}$ 台の墓所を主と すると答えた寺院が $37.5 \%$ と最も多く、より小規模の $1 \mathrm{~m}^{2}$ 未満の墓 所区画を主とする墓地が $30.9 \%$ であった。多摩地域については、3 $\mathrm{m}^{2}$ 以上という回答が $54.9 \%$ と半数を超え、 $1 \mathrm{~m}^{2}$ 未満の区画が多いと 答えた寺院は $5.9 \%$ にすぎかった。

墓所区画の使用状況をみるため、墓地のなかで使用されている区 画数を墓地の保有区画総数で除して使用率を算出した（表 3 ）。その 結果、76.5\%の墓地では全区画の 8 割以上が使用されていた。墓所 区画の使用率は全体的に高い。しかし、使用率の低い墓地が特定の 区市町村に集中する傾向がみられる。区部東部の足立区、葛飾区、 江戸川区と八王子市において 50〜 79\%という低い使用率の墓地が 目立つ ${ }^{15)}$ 。都内における墓地の需給バランスはエリアごとに差異が あるといえる。

次に、墳墓の形態についての回答をみる。社会の変化のもとで、 墓地には様々な形態の墳墓が設置されてきた。まず表 4 は多様な墓 石形態の使用状況について示したものである。多様な墓石形態とし て、洋風墓、デザイン墓、自由な言葉を彫刻した墓の使用状況を質 問したところ、いずれも $70 \%$ 以上の墓地においてすでに使用されて いるか、あるいは現時点で使用されていなくても使用を認めるとい う回答であった。従来仏教寺院で用いられてきた和型石塔型以外の 墓石も使用可能である墓地が多い。また近年では、家の者が承継・ 供養を行う家墓以外に、多様な納骨施設の設置がある。これに関す る回答をみると (表 5 )、不特定多数の遺骨が一箇所に納められ、寺 院が永代供養等の管理を行う「合葬式墓」の設置率が $38.7 \%$ であつ

\begin{tabular}{|c|c|c|c|c|c|c|c|c|}
\hline \multirow[b]{2}{*}{ 洋風墓 } & \multicolumn{2}{|c|}{ 使用あり } & \multicolumn{2}{|c|}{$\begin{array}{c}\text { 現在 } \\
\text { 使用なし、 } \\
\text { 認める }\end{array}$} & \multicolumn{2}{|c|}{$\begin{array}{c}\text { 現在 } \\
\text { 使用なし、 } \\
\text { 認めない }\end{array}$} & \multicolumn{2}{|c|}{ 合計 } \\
\hline & 139 & $(55.2 \%)$ & 58 & $(23.0 \%)$ & 55 & $(21.8 \%)$ & 252 & $(100 \%)$ \\
\hline デザイン墓 & 82 & $(33.1 \%)$ & 100 & $(40.3 \%)$ & 66 & $(26.6 \%)$ & 248 & $(100 \%)$ \\
\hline $\begin{array}{l}\text { 自由な言葉を } \\
\text { 彫刻した墓 }\end{array}$ & 114 & $(45.4 \%)$ & 81 & $(32.3 \%)$ & 56 & $(22.3 \%)$ & 251 & $(100 \%)$ \\
\hline
\end{tabular}

注）不明を除く。

\begin{tabular}{|c|c|c|c|c|c|c|c|c|}
\hline \multirow[b]{2}{*}{ 合葬式墓 } & \multicolumn{2}{|c|}{ 設置あり } & \multicolumn{2}{|c|}{$\begin{array}{c}\text { 現在 } \\
\text { 設置なし、 } \\
\text { 予定あり }\end{array}$} & \multicolumn{2}{|c|}{$\begin{array}{c}\text { 現在 } \\
\text { 設置なし、 } \\
\text { 予定なし }\end{array}$} & \multicolumn{2}{|c|}{ 合計 } \\
\hline & 98 & $(38.7 \%)$ & 58 & $(22.9 \%)$ & 97 & $(38.3 \%)$ & 253 & $(100 \%)$ \\
\hline $\begin{array}{l}\text { 個別の } \\
\text { 永代供養墓 }\end{array}$ & 49 & (20.8\%) & 41 & $(17.4 \%)$ & 146 & $(61.9 \%)$ & 236 & $(100 \%)$ \\
\hline 有期限墓 & 29 & $(12.0 \%)$ & 40 & $(16.5 \%)$ & 173 & $(71.5 \%)$ & 242 & $(100 \%)$ \\
\hline
\end{tabular}

注）不明を除く。 
表 6 現代の墓のあり方としての多様な墓に関する意見

\begin{tabular}{|c|c|c|c|c|c|}
\hline & $\begin{array}{l}\text { ふさわしい } \\
\text { と思う }\end{array}$ & $\begin{array}{l}\text { ふさわしい } \\
\text { と思わない }\end{array}$ & $\begin{array}{c}\text { どちらでも } \\
\text { ない }\end{array}$ & $\begin{array}{c}\text { わから } \\
\text { ない }\end{array}$ & 合計 \\
\hline 洋風墓 & $45(18.1 \%)$ & $73(29.3 \%)$ & $107(43.0 \%)$ & $24(9.6 \%)$ & $249(100 \%)$ \\
\hline デザイン墓 & $47(18.8 \%)$ & $(33.2 \%)$ & $93(37.2 \%)$ & $27(10.8 \%)$ & $250(100 \%)$ \\
\hline $\begin{array}{l}\text { 自由な言葉を } \\
\text { 彫刻した墓 }\end{array}$ & $59(23.5 \%)$ & $76(30.3 \%)$ & $93(37.1 \%)$ & $23(9.2 \%)$ & $251(100 \%)$ \\
\hline 合葬式墓 & $149(59.1 \%)$ & $(9.9 \%)$ & $48 \quad(19.0 \%)$ & $30(11.9 \%)$ & $252(100 \%)$ \\
\hline $\begin{array}{l}\text { 個別の } \\
\text { 永代供養墓 }\end{array}$ & $96 \quad(38.2 \%)$ & $77(30.7 \%)$ & $52(20.7 \%)$ & $26(10.4 \%)$ & $251(100 \%)$ \\
\hline 有期限墓 & $89(35.6 \%)$ & $(27.6 \%)$ & $46(18.4 \%)$ & $46(18.4 \%)$ & $250(100 \%)$ \\
\hline
\end{tabular}

たのに比べ、個別の永代供養墓」「有期限墓」の設置率はそれぞれ $20.8 \% 、 12.0 \%$ と低かった。これらの多様な墓石形態および納骨施 設を「現代の墓のあり方としてふさわしいと思うか」という設問で は（表 6 ）、「合葬式墓」「個別の永代供養墓」「有期限墓」という納 骨施設を「ふさわしい」とみな寸寺院が $59.1 \% 、 38.2 \% 、 35.6 \%$ で あったのに対し、多様な墓石形態の墓に関しては、「洋風墓」「デザ イン墓」「自由な言葉を彫刻した墓」を「ふさわしいと思う」と答え た寺院は $18.1 \% 、 18.8 \% 、 23.5 \%$ にとどまり、「どちらでもない」が $43.0 \% 、 37.2 \% 、 37.1 \%$ と多かった。寺院による永代供養や期限付き 使用の納骨施設は、実際に設置されるケースは少ないが、家墓の承 継が困難になってきたことを受けて必要性が認識され、ふさわしい と考えられることが比較的多い。これに対し、多様な形態の墓石に ついては、ニーズの高まりを反映して多くの寺院でその使用が可能 であるが、それがふさわしいと考えられることは少ない。

\section{$2-2$. 墳墓の改葬}

墳墓承継者の不在、管理料の滞納などによって墳墓の使用・管理 に不具合が生じると、墓所区画の使用権は消滅し、墳墓に納められ た遺骨が墓地内の別の場所へと改葬されたり、墓地使用の契約が解 除されたり寸ることがある。表 7 は無縁墓の改葬、および管理料滞 納墓所の契約解除のそれぞれについて、実施の有無と、実施に至る 年数を示したものである。これによれば、無縁墓の改葬を行ってい る寺院、管理料滞納による契約解除を実施している寺院の割合はそ れぞれ $45.5 \%$ 、 $25.5 \%$ となっており、半数に満たない。しかし後述 寸るように、無縁墓の増加、寺院と墓地使用者の付き合いの変化な どの動向のもとで、改葬・契約解除を行う寺院が増加することが予 想される。これらの寺院における、その実施に至る期間を比べると、 管理料滞納の墳墓の契約が解除されるまでの期間が、使用者不明と なった墳墓が無縁墓として改葬されるまでの期間に比べて短いこと がわかる。使用者不明の墳墓が改葬されるまでの期間を 20 年以上と 設定している寺院が 4 割、10 年以上が 7 割を超える一方で、管理料 滞納の場合は 9 年以内に契約を解除する寺院が $68.9 \%$ に達する。無 縁墓の認定は、「使用者不明の状態」をどの程度厳密に確かめるのか、 「使用者」とはどこまでの縁者を指寸のかなど、「無縁」の定義の不 明確さに関する問題をともなうのに対し、管理料滞納による契約解 除は、規約による明確な基準に基づき事務的に進められるため、短 い期間で実施されると考えられる。

\section{$2-3$. 墓地の敷地変更の経験}

寺院墓地の空間は不変ではなく、都市に長期にわたって存続する 間に様々な変容を重放てきた。墓地と墳墓区域の敷地について、拡 張・移転・縮小などの変更の経験を尋㸚たところ（図 1 )、「変更は なかった」と答えた寺院は $22.0 \%$ にとどまり、全体の 8 割近く
$(78.0 \%)$ の寺院が何らかの変更を行ってきたことがわかる。その 内容をみると、墓地の拡張 $(35.5 \%)$ 、移転 $(27.8 \%)$ 、墳墓区域の 拡張 $(21.6 \%)$ などが多い。移転の契機・理由としては、寺院の事 情は 4 件の夕であり、行政の事業（18 件）、関東大震災（17 件）、明 暦の大火（8件）など、寺院個別の事情から生じたのではない外的 要因が大半を占める (表 8 )。とくに、1923 年の関東大震災、1657 年の明暦の大火などの災害は、多くの寺院の移動を推し進めた。ま た、移転前後の墓地の所在地についての回答からは、墓地の郊外 の移転が促されたことがわかっている。関東大震災後の移転 17 件の うち 12 件、明暦の大火後の移転 8 件のうち 5 件が郊外に向かって移 転している ${ }^{16)}$ 。

\section{$2-4$. 墓地の経営・管理における問題点と対応}

様々な社会変容が進むなかで、何が寺院墓地の経営・管理上の問 題となり、寺院はどのような対応を実施・計画しているのだろうか。

まず経営・管理に関する問題点としては（図 2)、「新規で貸し付 けられる区画が不足している」 $(30.1 \%)$ 、「区画や通路が狭い」 $(23.2 \%)$ の回答率が高く、墓地用地の不足を問題として挙げる寺 院が多い。次いで「無縁墓が増加している」(22.4\%) が多く、墓地 承継の弱まりが墓地の運営における問題として認識されてきたこと がわかる。また、墓地用地の不足を問題と感じている寺院が多い一 方で、「使用されていない区画が多い」と回答した寺院の割合が $15.1 \%$ にんでいる。多くの寺院が墓地の敷地不足に悩んでいるの に対して、一部の寺院では墓地の余剩が問題となっている。

今後、墓地の敷地・施設に関して行いたいことに関する回答では (図 3 )、「施設全般の補修・改善」が約 4 割と突出して多い。その ほか、「新規開設」「拡張」「墳墓区域の拡張」など、墓地運営の規模 拡大を示唆する回答がそれぞれ 1 割強ある。また、「その他」の具体 的な回答としては「合葬式墓の建設」や「墓地内の区画整理」など が多く、寺院が新しい形態の墓地を模索する動きがみとめられる。 寺院が、墓地需要の高まり、無縁墓の増加などの傾向を踏まえ、そ れに対応するための具体的な構想をもっていることがわかる。

\section{2-5.まとめ}

ここまでのアンケート調查からわかったことを以下 3 点にまとめ ておく。(1)墓地の形態には地域差がみられる。市街地では墓所区画 と墓地敷地の規模が相対的に小さい寺院が多いのに対し、郊外では それらが相対的に大きい寺院が多数を占める。(2)墓地の需給バラン スには地理的な差異がある。区部東部や八王子市などでは未使用墓 所区画の割合が高く、墓地需要が相対的に低い。(3)墓地の規模や形 態は固定的ではない。多くの寺院は墓地の移転や拡張などを行い、 その敷地を更新してきた。墓石のデザイン、納骨方法などにおいて 新しい形態の墓が普及し、伝統的な和型の家墓のみが立ち並ぶ寺院 墓地は減少している。無縁墓の増加傾向を受け、寺院が墓所区画の 使用の短期間化、合葬式墓の設置等に取り組むことによって、寺院 墓地の空間変容が今後さらに進むと予想される。

墓地需要の高まりや墳墓承継問題の増加などの社会変化を踏まえ て、寺院は伝統的墓地管理のあり方とのバランスの保持に留意しな がら、多彩な墳墓をもつ新たな墓地空間を生み出してきた。それぞ れの寺院が、立地や使用者の属性といった寺院固有の条件に合わせ て独自の墓地空間を形成することで、都市全体でみると、墓地の多 様性が高まっているとみられる。 
表 7 無縁墓の改葬と管理料滞納墓所の契約解除

\begin{tabular}{lrrrr} 
& 無縁墓の改葬 & $\begin{array}{r}\text { 管理料滞納に } \\
\text { よる契約解除 }\end{array}$ \\
\hline く実施の有無〉 & & & & \\
行っている & 116 & $(45.5 \%)$ & 64 & $(25.5 \%)$ \\
行っていない & 139 & $(54.5 \%)$ & 187 & $(74.5 \%)$ \\
合計 & 255 & $(100 \%)$ & 251 & $(100 \%)$
\end{tabular}

\begin{tabular}{|c|c|c|c|c|}
\hline \multicolumn{5}{|c|}{ 〈実施に至るまでの年数＞ } \\
\hline ～4年 & 12 & $(11.8 \%)$ & 24 & $(39.3 \%)$ \\
\hline 5～9年 & 12 & $(11.8 \%)$ & 18 & $(29.5 \%)$ \\
\hline 10～19年 & 31 & $(30.4 \%)$ & 13 & $(21.3 \%)$ \\
\hline 20～49年 & 31 & $(30.4 \%)$ & 3 & ( $4.9 \%)$ \\
\hline 50～99年 & 9 & ( $8.8 \%)$ & 1 & $(1.6 \%)$ \\
\hline 100年～ & 1 & $(1.0 \%)$ & 0 & $(0.0 \%)$ \\
\hline 決めていない & 6 & $(5.9 \%)$ & 2 & $(3.3 \%)$ \\
\hline 合計 & 102 & $(100 \%)$ & 61 & $(100 \%)$ \\
\hline
\end{tabular}

注）不明を除く。 $\square$

\begin{tabular}{|c|c|c|}
\hline & 契機·理由 & 件数 \\
\hline \multirow{2}{*}{$\begin{array}{l}\text { 単独の } \\
\text { 契機 }\end{array}$} & 関東大震災 & 17 \\
\hline & 明暦の大火 & 8 \\
\hline & 戦兹 & $-\frac{2}{18}$ \\
\hline \multirow{3}{*}{$\begin{array}{l}\text { その他の } \\
\text { 理由 }\end{array}$} & 幕府の事業 & 6 \\
\hline & 火災 & 4 \\
\hline & 寺院の事情 & 4 \\
\hline . & 亮の他 & $-\frac{4}{16}$ \\
\hline
\end{tabular}

\section{3. 墓地の変容に関する寺院の意識と対応}

この章では、前章で行った寺院墓地の全体的な傾向に関する分析結 果を踏まえ、墓地または納骨堂を経営する寺院でみられる近年の変化、 及びそれへの寺院の意識と対応の内容を観察していく。具体的な事例 を集めることで、墓地と寺院の動向をより詳細に分析することが本章 の目的である。アンケート調查で回答を得た寺院のうち、承諾を得ら れた 53 件（区部 40 件、多摩地域 13 件）の寺院に対して、2005 年 12 月から 2006 年 2 月の間にインタビュー調查を実施した。調查対象に は納骨堂のみを経営する寺院を含んでいる。墓地使用者・墓地空間の 変化とそれに対する意見、墓地経営の状況などを質問し、住職をはじ めとする寺院関係者から回答を得た。以下の回答の引用については、 発言の主旨を明確化するために筆者が若干の編集を加えている。

\section{$3-1$. 墓地の需給関係}

まず、墓地の需給関係に関する回答を分析していく。インタビュ 一では、多くの寺院が、需要が数年前から若干の減少傾向にあるこ と、しかし団塊の世代の高齢化にともなって近い将来に急増すると 見込まれることについて述べている。具体的な回答としては、「昭和 20 年代だと 200 件ぐらいだった檀家数が、昭和 30 年から 60 年代に 急激に増えた」「 $5 、 6$ 年前に 200 区画売り出した分は、1、2 年で 完売した。3、4 年前まではどんどん売れていたが、現在はほかの 場所よりは……とうくらい」「団塊の世代で、もう一山墓地需要 が来ると思っている」などがみられた。

墓地需要に関する回答を寺院の立地別にみると、都心に近い寺院 では「墓地の使用希望は増えている。出身地ではなく、自宅に近い ところの墓地を探している人が多い」「檀家になりたい人は多い。近 所の人が多い」など、需要の多さを示す回答が多い。それに比心゙、 郊外の寺院では「この辺りでは、区画は小さいが安い霊園がたくさ んあって、墓地は余っている」「こ 5 年くらいで区画使用希望は減 っている」など、需要の少なさ、需要の縮小傾向に言及する割合が 高い。墓地の需給関係の地域差がここでも確認された。

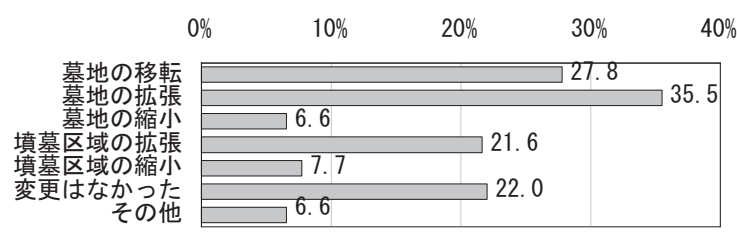

図1 墓地・墳墓区域の敷地に関わる变更の経験 ( $\mathrm{N}=259$ 、複数回答)

$0 \% \quad 10 \% \quad 20 \% \quad 30 \%$ けられる区画が不足している
使用されていない区画が多い
区画や通路が狭い 区画や通路が狭い

莫地内や周辺に緑が少ない

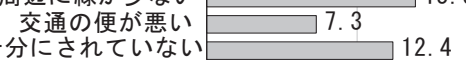

9.3 無縁墓が増加している 使用中止が増加している 墓参者が減少している

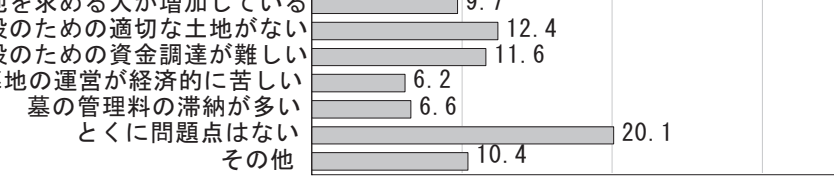

図2 墓地に関する問題点 $\quad(N=259$ 、複数回答 $)$

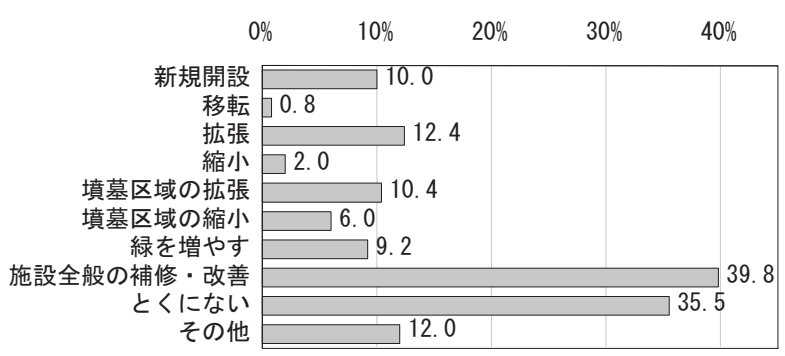

図3 墓地に関して今後行いたいこと（N=251、複数回答）

東京圈全体の需給関係に関しては、「バブル期にはみな土地がない 墓地がないと慌てて墓地の使用権を買っていたが、墓地が過剩に造 成され、その結果墓地は余っている」「墓地開発ブームで需給バラン スが崩れた。需要は満たされていると思う」「八王子や静岡に墓を建 てて、都心に帰ってきた人がいる。高齢になり、墓参に行けないケ 一スがある」「東京では、一時期みな郊外の霊園に墓をつくっていた。 それがだんだん近くになっている」などの回答がみられた。東京圈 の墓地は全体数としては充足しているが、都心に近いエリアでの需 要の拡大に合わせて、郊外を中心として墓地の余剩が顕著になるな ど、供給不足の地域と過多の地域への二極化が進んでいる、と考え ることができる。こうした需給関係の地域差を生み出寸因子として は、各墓地の交通利便性や歴史的背景に加え、高度成長期以降の墓 地開発ブームのもとで大量に供給された墓地との競合の度合いがあ ると考えられる ${ }^{17)}$ 。今後は、人口の都心回帰と、自宅の近くに墓を もちたいと考える人びとの増加などの動向が墓地の需給関係の地域 差に新たな影響を与えると推察される。

\section{$3-2$. 墓地使用者の属性と寺院との関わり}

次に、墓地使用者の属性の変化、および墓地使用者と寺院との関 わりの変化についてみていく。

まず、墓地使用者の居住地域をみてみると、寺院を中心として広 範囲にわたっていることがわかる。とくに古くからの檀家を多くも つ寺院において、墓地使用者の居住地の範囲は広い。これは、古く からの檀家ほど、親から離れた場所に住む子への墓地承継が繰り返 されていることが多いためである。逆に、新たに墓地使用を開始し 
た人びとは、寺院の近くに住んでいるケースが多い。

次に、墓地使用者の条件についてみる。従来、寺院墓地の使用者 は檀家に限定されていたが、現在では檀家以外も使用可能である墓 地が増えてきている。使用者を檀家に限定しない墓地の増加は、墓 地使用希望者が檀家用墓地を使用上の制約・負担が大きいと考えて 敬遠する傾向の強まりを反映している。とくに合葬式墓など、寺院 が永代供養を行う墓では、墳墓承継者がいない、あるいは墳墓の承 継を望まない個人や夫婦による使用が多いため、使用者に檀家関係 を結ぶことを義務づけない寺院が多い。信仰・葬儀法要・墓地の使 用が一体となっていた従来の寺檀関係に当てはまらない、墓地使用 者と寺院の関わりの新しい類型が現れてきたことがうかがえる。

墓地使用者の家と家族に関わる変容について尋齐たところ、「独り 身の人、子供がいない人が増えている」という回答を典型として、 多数の寺院が核家族化・少子化の進行、無配偶者の増加傾向につい て述べた。また、寺院で行う法要が小規模になっていることから、 家、親類、近隣、勤め先などにおける人びとの関係の希薄化を指摘 する寺院が多くみられた。こうした墓地使用者の変容のもとで、個 人や親類、婚姻関係で繋がる複数の家族など、様々な単位での墓地 使用希望が増加している。家を単位としない墓の広まりを受け、「家 に固執せず、それぞれの縁で墓に共同で入って、守って、信仰が高 まればいい」という意見をもつ寺院もみられた。

墓地使用者の変化と同時に、寺院と墓地使用者との関係も変容し てきた。「家の変化、親との別居の増加などによって、寺との関わり 方が世代間で伝承されないことが増えた」「寺檀関係をひとつずつ説 明しないとわからない人が多くなってきている。親から伝わってい ないので仕方がない」隣近所の付き合いが希薄で、付届けなどを寺 にいくら納めるものかもわからない人が増えている」など、寺院と の付き合い方に関して、檀家内での世代間伝達や檀家同士の助言の 減少を示唆する回答が多い。寺院と使用者の間で慣習として続いて きた諸々の付き合いの濃度が低下していると推察される。

このことを反映して、墓地使用に関わる規約を新たに設ける寺院 の増加傾向がみられる。従来、墓地使用については、寺院と使用者 が面談などを行い、口頭で取り決めてきた。しかし近年では明文化 した規約を定め、その規約に基づいて墓地使用者と契約を交わ寸寺 院が増えている。「寺と檀家・地域との信頼関係があれば規則はいら ないが、薄らいでくるとつくらざるを得ない」「寺との付き合いに関 する知識や意識が、檀家の親から子一伝わらなくなった。そのため、 代替わりのときに規定を渡して自覚してもらう」「現在は、規則など についてあえて言う必要がない。しかし、いずれは規則が必要にな るかもしれない」と述べる寺院があった。使用者との付き合いが縮 小寸るなかで、意思疎通・情報伝達の不足によるトラブルを予防す る一手段として、規約を導入する寺院が増加してきたと考えられる 18)。ただし、これらの寺院が、導入した規約を厳密に適用するとは 限らない。「改葬の規定の導入は、問題が生じないための予防策。墓 地を借りるということの意識付けの意味がある。実際には、改葬を 事務的にはできない」「寺と檀家の関係は、解約事項が発生したから 『はい、それで終わり』とはいかない。それぞれの事情もあるし、 いつかは使用者が問題に対応してくれるから待つ」などの回答が示 すように、実際の墓地運営において、多くの寺院は、規約内容に固 執せず、柔軟な対応を行っている。

\section{3-3. 墓地・墳墓の形態と無縁墓の状況}

墓地需要の拡大、家制度の弱まりといった動きのもとで、寺院墓 地はその物理的空間をどのように改編してきたのか。墓地の空間的 変容として、墓地・墳墓の形態と無縁墓の状況について尋ねた。

まず墓地と墳墓の敷地については、ひとつひとつの墓所区画を小 規模化すると同時に、全体の墳墓区域を拡大しようとする寺院の動 きがみとめられる。「墓所の設定を小さい区画にしたのは、なるべく 多くの人に檀家になってほしいし、安い方が求めやすく、求める人 が多いから」「できれば拡張をしたい。檀家の負担を少なくするため に小規模で低廉な区画を主につくりたい」という回答が示すように、 その主要な目的は、量的需要への対応と使用者の経済的負担の軽減 である。なかでも納骨堂は、高密な納骨が可能であること、遺骨を 屋内に収蔵寸るため設置場所に関して公衆衛生に関わる規制を受け ず ${ }^{19)}$ 、都市部にも開設しやすいことなどから、墓地に替わる形態の 施設としてその導入が進んでいる ${ }^{20)}$ 。納骨堂経営寺院の意見として は、「納骨堂は少子化、個人化、意識の変化に対応寸る形」「人口密 集地帯で墓を受け入れるならビル形式。企業中心の墓地開発で山野 が切り開かれることに対するひとつの提案だった」土地があれば墓 地を経営したいが、開設できるとしたら郊外になり、お参りに来る 人も少なくなるだろうから、今はできない」などの回答があった。

寺院墓地の多くでは、家制度の摇らぎを背景とする空間変容が進 んでいる。家墓の承継の困難化を反映した現象のひとつは無縁墓の 増加である。調査時点で使用者がすでに不明である墓は多くはない。 しかし多くの寺院が今後における無縁墓の増加を予想し、それに対 応するために墓地空間の改編を進めている状況がみてとれる。墳墓 の承継者が絶えた場合には、「親戚でひとつの墓に入っているところ も何件かある」使っている人が承知しているなら誰が入っても構わ ない。しっかり守れればみんなで使っていいと思う」など、親族や 友人同士での墳墓の共同使用を認める寺院が多い。墳墓の建立段階 で、墓石に刻む文字に関して「今後建てるときには『南無阿弥陀仏』 を勧めている。少子化で、子孫以外で誰が墓に入るかわからなくて も続けて使えるので」など、使用者を家の者に限定しないよう、家 名以外の文字を採用することを勧める寺院もみられた。

さらに、承継者不在の問題に対する寺院の積極的な取り組みとし て、合葬式墓の設置が挙げられる。合葬式墓は、初めから墓を建て ない人と、墓の承継ができなくなった人のために設けられている。 設置の経緯としては「特定の家の墓というものに疑問を感じた。一 方で、少子化、核家族化があり、子は親と住まなくなっている。そ のことによって墓も住まいと離れた場所になり、管理をどうするの かという問題が起こる。このよう背景があり、合葬式にした」「永代 供養墓（合葬式墓）は、ここの墓地に墓があって跡継ぎのいない人 の受け入れ先として設けた」などの回答があった。また、「合葬式墓 が必要である背景には、経済的に墓を建てられない人の問題もある だろう」経済的に差別が生じないようにするために、共同供養墓(合 葬式墓) をつくった」というように、墓所区画の小規模化と同様、 低廉な納骨施設の供給を意図している寺院があった。

墓石の形態は、洋風墓やデザイン墓が増えるなど、多様化してい る。墓石に刻む文言等に関しては、「洋風墓には、ほとんど『夢』『絆』 『寂』などの文字が入っている」『『家之墓』は、新規設置の墓石 では半分程度。家紋代わりに自分の好きな模様や絵を入れる人もい 
る」など、その種類が増えていることを示す回答がみられた。「デザ イン墓は、個人単位の墓で増えていくだろう」「墓石の形を好きにす るのは建立者の考えで、それを妻は理解するだろうが、子や孫は納 得できるかという疑問はある」という寺院があるように、こうした 形態の墓石の増加は、墓に対する使用者の認識が、家の者が代々使 うものから、自分個人のものへと変容していることを示唆している と考えられる。寺院が墓石の形態を厳しく規制することは少ない。 新しい意匠の墓石を受け入れる寺院の意見として、「墓石の形はどん なものでも構わない。人に不快感を与えない、公序良俗を乱さない もの、異宗教でなければよい」「墓石の形については、『よく相談し ましょう』『長いスパンで考えよう』と建立者に言う。跡をとる人が よかったと思えるならいい」「墓石に刻む言葉としての『〜家之墓』 自体が明治以降に導入された新しいものだから、刻む言葉は自由で いいと思う」などの回答があった。

\section{$3-4$. 墓地・寺院の経営}

最後に、墓地と寺院の経営についての質問の回答をみていく。 東京の寺院では地方に比べて、墓地使用者数を維持しやすく、そ のほかの葬儀・法要依頼も多いことから、経営における財政的な問 題は少ないと推察される。しかし、寺院墓地、とくに檀家用墓地を 敬遠する風潮の強まりを感じ、一定の使用者数を確保するために、 公営墓地や民間業者主導で経営される墓地にはない、寺院特有の墓 地運営のあり方を模索する寺院がみられた。具体的には、「寺として は、いかに家族で寺院や墓地に来させるか。そのために昔のカルチ ヤーセンターとしての役割を復活させて、敷居を低くしたい」「個別 の永代供養墓には、結婚しない女性など、希望者は多い。このよう な墓を用意しておいて色々な状況に対応することは、業者ではでき ない。信頼関係で話し合える寺だからできる」「寺は、コミュニケー ションがとれ、相談などもできる」など、墓地使用という死後の関 わりだけでなく、使用者との生前の交流を重視する寺院が多かった。

また、墓地経営における試みのひとつとして、宗旨不問の霊園を 開設している寺院がある。霊園を運営することの位置づけについて は、「墓地と寺はあまり密接な関係ではない。寺院の主な活動は、布 教・伝道にしたい」など、墓地の公益的性格を重視し宗教活動とは 別の活動として捉えている寺院がある一方、「霊園使用者にも後々は 寺との付き合いが出てくるかもしれないし、長い目で見て縁のある 人はいずれこの寺に来るだろうと考えている」「霊園運営は新しい布 教の形かと思う。墓地を提供して寺と住職を見てもらい、時間が経 ってからでも寺を評価してもらえたらいいと思う」というように、 布教活動の一環と考えている寺院があった。

墓地の運営にあたって障害となる事柄については、まず、墓地を 規制する法令や行政の対応に関する回答が多かった。とくに、「無縁 墓の改葬について、官報に載せる意味がわからない。誰が見るのか。 トラブル回避のためでしかないだろう」「法律は、住宅地からの距離 制限など、経営には厳しすぎる」など、無縁墳墓の改葬規定、ある いは都の条例による「墓地から民家等までの距離は $100 \mathrm{~m}$ 以上」と いう規定 ${ }^{21)}$ の合理性を疑問視する意見が目立つ。また、墓地の開 設や拡張の許可を受ける際の、近隣住民からの理解を得ることの難 しさについて話寸寺院があった。「霊園をつくる際、周辺の承諾を得 るのは大変で、一年くらいかかった。マンションのオーナーや管理 者は『土地の価格が安くなる』と言った。何回か集まって交涉した」
「拡張したとき、業者を仲介せず、近隣の署名をもらうなど大変だ った。30 軒判子が必要だったうち、2 軒に反対された。結局、当初 の 600 坪の拡張計画を半分にした」などの具体例がみられる。住民 が墓地開発を好まない一因として、かつて民間業者主導の墓地開発 においてトラブルが発生したことに言及する寺院もあった。墓地が 隣接地に出現することによって所有地の価格下落を予想する人が多 いことをはじめ、周辺住民は墓地開発に対してネガティブなイメー ジをもっており、そのことが墓地経営上の障壁となっている。

\section{3ー5. まとめ}

核家族化、少子化といった様々な社会変化のなかで、家制度の自 明性は低下し、家族・親類内での個々人間の関係は変容してきた。 それに伴い、家を単位としない墓地・墳墓の使用が増加しつつある。 墓地使用・葬儀・法要・布施などが一体でない寺檀関係が現れ、寺 院と墓地使用者の付き合いのパターンは多様化している。和型の家 墓が並ぶ中に洋風墓、デザイン墓が増え、合葬式墓や納骨堂の設置 が進むなど、墓地の形態と使用方法の幅は広がっている。

こうしたインタビュー調查の結果からわかるのは、都市の寺院と その墓地が、檀家・墓地使用者との関係、使用者の条件、墳墓共有 者、祭祀供養のあり方、墓石の形態、墓石の彫刻の内容、墓所区画 の規模など、多彩な側面において伝統と変化を兼祆備えることで、 社会の動きに対応し、使用者のあらゆる需要に応えている、という ことである（表 9 )。寺院は社会の変化を捉え、それに合う墓地のあ り方を模索し、墓地空間を柔軟に変容させることで、都市の中に存 続してきた。

表9 都市の寺院墓地における伝統と変化

\begin{tabular}{l|ll}
\hline & 伝統 & \multicolumn{1}{c}{ 変化 } \\
\hline 墓地使用関係 & 信頼関係で成り立つ & + 規約で明文化、契約書を使用 \\
使用者の条件 & 檀家に限る & + 緩やかな条件を設ける、条件を設けない \\
墳墓の共有者 & 家の成員に限る & + 親類、友人、両家墓を認める \\
祭祀供養 & 家の者が行う & + 寺院が永代供養を行う \\
墓石の形態 & 和型で統一 & + 洋風墓、デザイン墓を認める \\
彫刻の内容 & 戒名や家名等を刻む & + 自由な言葉、絵や写真を認める \\
墓所区画の規模使用者により大小様々＋小規模なものを中心に用意
\end{tabular}

\section{4. 結論}

ここまでに行ってきた調査結果の要約として、都市に立地する寺 院墓地の変容について次の 2 点が指摘できる。第一に、核家族化・ 少子化・無配偶者の増加等を背景として、寺院と墓地使用者の関係 には様々なパターンが現れてきた。従来の家墓に加え、夫婦や個人、 親類や複数の家族といった単位における墓地使用が普及寸る傾向が ある。墓地使用、葬儀、法要などが一体となった寺檀関係だけでは なく、檀家ではない人びとによる墓地使用、墓地使用以外では寺院 との関わりをもたない人びとの増加など、寺院と墓地使用者の新し い関係が生まれてきた。第二に、寺院は伝統に則った墓地運営を続 けるだけではなく、こうした様々な社会変化を受けて、使用者との 関係や墳墓の形態といった多岐にわたる側面において柔軟に変容す ることで、新しい墓地のあり方を検討している。寺院は、旧来の寺 檀関係に基づく家単位の墓地使用者を中心に据えながらも、それ以 外の人びとのための合葬式墓などを用意したり、和型以外の墓石、 様々なデザインの墳墓の設置を受け入れたりするなど、新たな取り 組みを続けている。

ここまでの分析結果から、都市における寺院墓地の役割について 
何が言えるのだろうか。これまでの墓地に関連する政策は、市街地 における狭小墓地の新規開発を抑制し、その郊外移転の促進を主眼 に据えてきた。しかし、人びとは都市の中に墓地を必要としている。 人口の都心回帰が進み、高齢者を中心として墓を自宅の近くにもち たいという志向が強くなってきている。墓地を都市から取り除くの ではなく、都市空間の中に維持していくことの必要が高まっている。 このことを踏まえたとき、都市に立地する寺院墓地は、都市の重要 な空間構成要素として位置づけられるべきではなかろうか 22) 23)。市 街地に散在する寺院墓地は貴重な墓地供給主体であると同時に、宗 教・信仰の場、緑地・空地を形成し、寺院と地域の関係をつくる機 能をも有している。そして、寺院墓地は、社会の変化に対応して自 ら変容し、都市空間に存在し続けることを可能にする柔軟性をもっ ている。現代の寺院墓地は、伝統的な墓地のあり方を踏襲寸るだけ ではなく、様々な工夫を重衩て、新たな形態の墓を受け入れ、墓地 使用者との新しい関係を築いてきたからこそ、都市の中に存続して きた。今回のアンケート調査では有効票回収率が 1 割を下回ってお り、ここで得られた結果が現在の寺院墓地の全体像を描いていると は言い切れない。墓地経営における変化に関心を持つ寺院が、アン ケート及びインタビューへの回答により好意的であった可能性があ る。しかし調查結果は、様々な社会変化のもとで、寺院が墓地空間 のあり方を再考しようとする動き、墓地空間を実際に造り替える動 きがあることを示している。人口の高齢化と少子化、無配偶者の増 加、家族のあり方の変容は今後ますます加速すると見込まれる。都 市に立地する寺院墓地の役割をあらためて評価していく必要がある。

\section{謝辞}

本研究で実施したアンケート調查、およびインタビュー調査においては、 東京都に所在する多くの寺院関係者から多大な協力を得ました。ここに記し て御礼申し上げます。

\section{注および参考文献}

1）家墓は家族内での世代間承継を前提とした墓である。家墓の普及は家制度 を背景としている。家族の永続性を重視する家制度は祖先崇拝の民間信仰 との補完関係を形成し、家墓を広めた。1 872 年の戸籍法、1 898 年の民法の 施行により家制度の法基盤が整備されたこと、火葬の一般化により複数の 納骨が可能になったことなどが、家墓の普及を推し進めた。

2）井上治代 : 墓と家族の変容, 岩波書店, 2003, 槙村久子: [都市型共同墓所] の構築と地縁・血縁を超える墓地の方向, 造園雑誌, 第 57 巻 5 号, pp. 109-114, 日本造園学会, 1994, 樃村久子: お墓と家族, 朱鷺書房, 1996, 森謙二: 墓々葬送の現在一祖先祭祀から葬送の自由へ, 東京堂出版, 2000 など。

3）川越美穗: 講座 都市と埋葬 東京における墓地行政の展開一青山霊園を 事例に, 歷史と地理, 第 582 号, pp.40-50, 山川出版社, 2005, 藤井正雄 : 現代の墓地問題とその背景, 藤井正雄・義江彰夫 - 孝本貢 (編) 家族と 墓, 早稲田大学出版部, pp.6-24, 2003 などが東京の墓地移転について、名 古屋市計画局戦災復興誌編集委員会: 戦災復興誌, 名古屋市計画局, 1984, 新修名古屋市史編集委員会 (編) : 新修名古屋市史第 7 卷, 名古屋市, 1998 などが名古屋市の墓地移転について触れている。また、移転を免れた墓地 についても、東京市では大正 15 年告示の「特殊納骨設備承認手続」の第三 条三に「外壁ノ高サ八床盤面ヨリ六尺以上ナルコト」と定められているな ど、墓地を周辺から遮蔽することが求められたことがわかる。

4) 井下清: 建墓の研究, 雄山閣, 1942, 建設省「墓地計画標準」などを参照。

5）東京都建設局: 都市型墓地に関する意識調查報告書, 東京都建設局, 1995 によると「お墓を求める場合に重視する点」(複数回答) は「自宅からの 距離・交通の便」が $71.0 \%$ と最も多く、以下、「墓石工事費も含めた総費 用」 $(44.2 \%)$ 、「墓地の永代使用料」 $(36.2 \%)$ と続く。
6）東京都は公営墓地の郊外移転を進める政策の一環において、区部に立地す る 4 籄所の公営墓地（青山霊園、谷中霊園、雑司ヶ谷霊園、染井霊園）を 都市計画公園として 1957 年に都市計画決定し、青山霊園と谷中霊園では 1960 年に、雑司ヶ谷霊園と染井霊園では 1962 年にその墓所区画の新規貸 付を停止した。しかし都心部における墓地需要は高く、近年になって東京 都は区部の公営墓地に対する政策を変更した。東京都公園審議会による 2002 年の答申に基づき、青山霊園の再生事業が始まり、墓所貸付が 2003 年に再開した。これに続く 2005 年の答申では谷中霊園の再生事業の方針が 提案された。東京都公園審議会：「区部霊園の管理について」答申, 2002, 同 :「谷中霊園再生のあり方について」答申, 2005 などを参照。

7）森謙二：墓地関する意識調査，平成 9 年度厚生科学研究，1998 による と、「将来あなたが入るお墓を継いでくれる人がいますか」という問いに 対し、「決まった人がいる」と回答した割合は、全国では $51.2 \%$ 、東京都 区部のみでは $43.3 \%$ あ゙あり、そのほかの都市についても都市規模が大き いほど概して低い。

8）前掲東京都建設局, 1995 を参照。

9）東京都建設局：東京都霊園問題調查会報告書，東京都建設局，1988 などを 参照。

10）波平恵美子：日本人の死のかたち一伝統儀礼から靖国まで，朝日新聞社， 2004, 江戸遺跡研究会編 : 墓と埋葬と江戸時代, 吉川弘文館, 2004 など。

11）前掲川越，森謙二 : 明治初年の墓地及び埋葬に関する法制の展開一祖先祭 祀との関連で一, 藤井正雄・義江彰夫・孝本貢（編）家族と墓, 早稲田大 学出版部, pp.197-229, 2003 など。

12）八木澤壯一・武田至・庄司豪幸：東京都区部の寺院墓地の実態と都心墓 地の可能性について, 日本建築学会 1999 年度大会 (中国) 学術講演梗概 集(E1)，pp.497-498，1999，吉田禎雄・千葉一輝・龍治男・ 戸沼幸市：東 京の寺町に関する研究 その 10 . 東京都心部の寺院特設墓地について, 日本建築学会 1994 年度大会 (東海) 学術講演梗概集(F), pp.677-678, 1994 など。

13）前掲井上，2003，前掲梖村，1994，1996など。

14）東京都生活文化局都民協働部市民活動推進課 : 東京都宗教法人名簿平成 16 年度版，東京都生活文化局都民協働部市民活動推進課，2004。

15）足立区、葛飾区、江戸川区と八王子市では、区画使用率 50 ～79\%の墓地 の割合がそれぞれ $35.7 \% 、 50.0 \% 、 36.4 \% 、 40.0 \%$ であった。

16）現在の区市町村境界を越え、なおかつ都心からの距離が遠くなる方向へ の移転を集計した。

17）多摩地域の法人墓地の台帳（2004 年 11 月現在）によると、同地域におけ る法人墓地面積の約 $53 \%$ を 1960 年以降に経営許可を受けた墓地が占め、 その大部分 $(75.1 \%)$ を $10,000 \mathrm{~m}^{2}$ 以上の大規模墓地が構成している。

18）厚生省は、平成 12 年「墓地経営・管理指針等作成検討会報告書」のなか で、事業型墓地について「墓地使用に関する標準契約約款」を示し、「公 共性のある事業型墓地については特に、墓地使用契約の内容について利 用者保護の観点から明確化等を図ることが必要」としている。

19）東京都「墓地等の構造設備及び管理の基準等に関する条例」第 8 条。

20）「東京都衛生年報 1978～2005」によると、都内（島嶼部を除く）の納骨堂 数は 1978 年の 146 から 2005 年の 300 へと着実に増加している。

21）東京都「墓地等の構造設備及び管理の基準等に関する条例」第 6 条三。

22）前掲 6)でみたように、東京都は、都心部での墓地需要の高まりを受け、 区部に立地する公営墓地の再生事業に着手し始めた。都市空間に墓地を 保持することの重要性は、こうした行政セクターの動きにも表れている。

23）長江・八木澤は、都市に立地する墓地の管理システム上の問題点を明ら かにし、都市における墓地を祭祀生活施設として永続的に管理していく ことの必要性を指摘している。長江曜子・八木澤壯一: 持続可能な墓地再 生と墓地永続管理システムの研究一宮崎市営墓地・都立青山霊園再生を中 心として一，日本都市計画学会都市計画論文集 No.42-1，pp.25-31，2007。

(2007年 9 月 3 日原稿受理，2008年 3 月 10 日採用決定） 